Meta

Journal des traducteurs

Translators' Journal

\title{
"Prompt, at any time of the day...": the Emerging Translatorial Habitus in the Late Habsburg Monarchy
}

\section{Michaela Wolf}

Volume 58, numéro 3, décembre 2013

URI : https://id.erudit.org/iderudit/1025048ar

DOI : https://doi.org/10.7202/1025048ar

Aller au sommaire du numéro

Éditeur(s)

Les Presses de l’Université de Montréal

ISSN

0026-0452 (imprimé)

1492-1421 (numérique)

Découvrir la revue

Citer cet article

Wolf, M. (2013). "Prompt, at any time of the day...”: the Emerging Translatorial Habitus in the Late Habsburg Monarchy. Meta, 58(3), 504-521.

https://doi.org/10.7202/1025048ar
Résumé de l'article

Faisant partie des concepts clés de la sociologie française, la notion d'habitus a conquis le domaine de la traductologie, du moins dans le cadre de la sociologie de la traduction. Le présent article vise à mettre en évidence, de façon critique, les principaux facteurs expliquant le potentiel du concept d'habitus en traductologie. Discutant de son adoption au sein de la traductologie, notre objectif est remettre en question l'allégation constante de l'état de soumission du traducteur prétendument lié à l'habitus traductionnel. Se fondant sur une étude de cas portant sur la traduction en pratique privée (professionnelle) dans le contexte de la fin de la Monarchie des Habsbourg, notre étude se concentre sur trois aspects appuyant l'hypothèse selon laquelle, vers la fin du $\mathrm{xix}^{\mathrm{e}}$ siècle, la traduction professionnelle se caractérisait par un processus d'émancipation explicite, essentiellement motivé par un combat visant à la reconnaissance de cette activité : la faiblesse structurelle initiale du domaine ; l'habitus en tant que produit de la relation entre les histoires collective et individuelles ; les conditions stimulant le dynamisme de l'habitus du traducteur. Nous proposons une vision originale du concept d'habitus qui remet en cause les propos habituellement tenus sur sa valeur informative.
Ce document est protégé par la loi sur le droit d'auteur. L’utilisation des services d'Érudit (y compris la reproduction) est assujettie à sa politique d'utilisation que vous pouvez consulter en ligne.

https://apropos.erudit.org/fr/usagers/politique-dutilisation/ 


\title{
"Prompt, at any time of the day...": the Emerging Translatorial Habitus in the Late Habsburg Monarchy
}

\author{
MICHAELA WOLF \\ University of Graz, Austria \\ michaela.wolf@uni-graz.at
}

\section{RÉSUMÉ}

Faisant partie des concepts clés de la sociologie française, la notion d'habitus a conquis le domaine de la traductologie, du moins dans le cadre de la sociologie de la traduction. Le présent article vise à mettre en évidence, de façon critique, les principaux facteurs expliquant le potentiel du concept d'habitus en traductologie. Discutant de son adoption au sein de la traductologie, notre objectif est remettre en question l'allégation constante de l'état de soumission du traducteur prétendument lié à l'habitus traductionnel. Se fondant sur une étude de cas portant sur la traduction en pratique privée (professionnelle) dans le contexte de la fin de la Monarchie des Habsbourg, notre étude se concentre sur trois aspects appuyant l'hypothèse selon laquelle, vers la fin du XIX ${ }^{\mathrm{e}}$ siècle, la traduction professionnelle se caractérisait par un processus d'émancipation explicite, essentiellement motivé par un combat visant à la reconnaissance de cette activité: la faiblesse structurelle initiale du domaine; l'habitus en tant que produit de la relation entre les histoires collective et individuelles; les conditions stimulant le dynamisme de l'habitus du traducteur. Nous proposons une vision originale du concept d'habitus qui remet en cause les propos habituellement tenus sur sa valeur informative.

\section{ABSTRACT}

As one of the key notions in French sociology, habitus has also lately conquered the field of translation studies, at least from the perspective of a sociologically-oriented view of translation. In this paper I will critically highlight the main factors responsible for the term's potential for translation purposes. Within the discussion of its adoption in translation studies, I will test the enduring claim of the translator's submissiveness allegedly related to the translatorial habitus. On the basis of a case study on the private (commercial) translation sector in the late Habsburg Monarchy, I will focus on three aspects to substantiate my assumption that towards the end of the nineteenth century, the commercial translators' activity was already characterized by explicit emancipating processes, mostly driven by the struggle for recognition in the field: the initially weak structure of the field; the habitus as a product of the relation between its collective and individual history; the conditions triggering the dynamism of the translator's habitus. I will attempt to develop a differentiated view on the habitus concept, challenging traditional discussions of its informative value.

\section{MOTS-CLÉS/KEYWORDS}

habitus, pratique professionnelle, Monarchie des Habsbourg, histoire de la traduction habitus, professional field, Habsburg Monarchy, translation history 


\section{The last 2000 years of habitus}

The concept of habitus was introduced to modern usage by the German-American art historian Erwin Panofsky ${ }^{1}$ from scholasticism, and especially from St Thomas Aquinas. He used the term habitus in his opus magnum Summa Theologiae to refer to the four intellectual virtues - art, science, understanding and philosophical wisdom - which are necessary for participation in society. For him, habitus occupies a sort of in-between position; it is a mediating force between potentia pura - potentiality - and the execution of an action, purus actus. Accordingly, St. Thomas distinguishes between various forms of habitus, such as habitus activus, habitus corporis, or habitus operativus. (Malikail 2003; Krais and Gebauer 2002: 26).

In line with the medieval scholars, who drew on influences from the Arabic tradition, his philosophy goes back to Aristotle. By hexis, the Greek word for habitus, Aristotle meant those acquired virtues which were the prerequisites for a righteous life: temperance, fortitude, justice and prudence. For Aristotle, habitus is created on the basis of experience and through various actions memorized by the subject through physical processes; on the other hand, memory is a structuring factor for future action: hexis is, contrary to images based on memory, the non-intellectual capacity for the creation of action. On this basis, hexis can produce values and has the potential to create knowledge (Krais and Gebauer 2002: 29). ${ }^{2}$ This ethical dimension prevails in the usage of the term throughout the Middle Ages and up to Martin Luther. Luther, however, marks a caesura with reference to habitus: his focus is on an immediate experience of God and, closely connected to this claim, an emphasis on the dimension of feeling (Nickl 2001: 118), thereby turning away from the intellectual edifice of scholasticism.

Habitus fell into disuse after the sixteenth century, when Latin ceased to be the language of philosophy. Since then, habitus has been generally translated into habit, with all its conceptual limitations. The anthropologist Marcel Mauss used habitus to denominate those aspects of culture that are anchored in the body or daily practices of individuals and groups, including the learned habits, bodily skills, styles, tastes and other non-discursive knowledge. ${ }^{3}$ Norbert Elias focused on the explicitly social side of the habitus, which he saw as the societal basis for the personal characteristics which represent a distinctive feature for the individual (Elias 1987: 244).

Pierre Bourdieu's concept of habitus is still the most elaborated in present times. He recognizes the Aristotelian-Aquinian roots of his habitus concept (Bourdieu 1992: 29), but never explicitly delivers more details on this linkage. Drawing on the works of Marx, Durkheim, and Weber, Bourdieu developed a theory of social and cultural production that tried to be free from deterministic and mechanistic causality and addresses issues such as the relationship between cultural practices and broader social processes, the social position of intellectuals and artists, the connections between systems of thought, social institutions and different forms of material and symbolic power. Within this framework, habitus, together with field and capital, are the central thinking tools.

One of Bourdieu's major claims is to transcend the choice between subjectivism and objectivism: "Subjectivism inclines people to reduce structures to interactions, objectivism tends to deduce actions and interactions from the structure" (Bourdieu 1990a: 129; translated by Adamson). According to Bourdieu, social life cannot be 
understood as the aggregate of individual behaviour, nor can social practice be seen as determined by supra-individual "structures." Human action is thus not deterministically trapped between mechanistic and finalistic interpretations. Rather, the concept of habitus helps bridge the gap between these various extremes by referring to socially acquired, embodied systems of dispositions and predispositions (see Scahill 1993). Hence, it refers not to character, morality, or socialization per se, but to "deep structural" classificatory propensities and generates the tastes, preferences, body-language, prejudices, and so on, of a given class or class fraction, across all different fields of practice. The definitions of habitus delivered by Bourdieu vary widely; one of the most quoted is that habitus is the system of

[...] durable, transposable dispositions, structured structures predisposed to function as structuring structures, that is, as principles which generate and organize practices and representations that can be objectively adapted to their outcomes without presupposing a conscious aiming at ends or an express mastery of the operations necessary in order to attain them. (Bourdieu 1977: 72; translated by Nice)

As can be seen, habitus is not thought of as a fixed essence operating like a mechanism determining mental or behavioural outcomes. On the contrary, Bourdieu stresses that "there is nothing mechanical about the relationship between the field and the habitus" (Bourdieu 1993: 65; translated by Nice). This relationship is instead determined by the nature of its structures, habitus being described as an internal, subjective structure born from the incorporation of the external, "objective" structures of the field.

A range of other issues demand further discussion when considering Bourdieu's definition of habitus. First of all, the term "disposition," used in most definitions to describe the nature of habitus, is more than "attitude"; more precisely, it also includes the cognitive and affective factors of thinking and feeling. Furthermore, Bourdieu refers repeatedly to dispositions as something beyond consciousness, the habitus being acquired by individuals through experience and explicit socialization in early life (Jenkins 1992: 77). He also insists on the generative capacities of dispositions and emphasizes their historical momentum. As a shared body of dispositions and generative schemes, the habitus is seen as the outcome of collective history: "The habitus, a product of history, produces individual and collective practices [...] in accordance with the schemes generated by history" (Bourdieu 1990b: 54; translated by Nice). However, the habitus is not only the product of individual history, but also, through the long process of inculcation beginning in early childhood, of the whole collective history of family and class.

Another important characteristic of the habitus is its "durability." Bourdieu insists that the dispositions governing and driving the habitus are not "permanent," but "lasting," as social agents are continually transformed by social experiences, in the same way as the "durable and transposable (cognitive and bodily) structure that results from initial experiences may itself be transformed” (Bourdieu 1991: 32). Consequently, Bourdieu claims that the dispositions are both structured and structuring. They are "structured structures" in that they always incorporate the objective social conditions of their inculcation, and they are "structuring structures" through their ability to generate practices adjusted to specific situations (see Johnson 1993: 5). The habitus is thus exposed to continuous constraints, but at the same time involves 
a significant creative dimension. This is best reflected in Bourdieu's thoughts on the interface of theory and practice in a sociological view:

To change the world, one has to change the ways of world-making, that is, the vision of the world and the practical operations by which groups are produced and reproduced. (Bourdieu 1989: 23)

This quotation reveals the connection between structure and human action. The classifications and distinctive principles inscribed in the habitus are reflected in the practices of daily life and in their potential to alter existing structures.

In the context of translation, habitus can be understood as secondary habitus. It is continuously formed on the basis of the primary habitus shaped during childhood and is significantly marked by the profession of translators. General critics of Bourdieu's habitus concept claim that the overall emphasis on the primary socialization of individuals and the corresponding disregard of successive learning processes create a problematic analogy of psychical and social factors. This claim can be asserted for the translatorial habitus in the context of the social practice of translators, which is heavily marked by the conditions of the labour field. The postulate that the habitus of an individual or a collective can be reconstructed through his or her various activities (see Krais and Gebauer 2002: 26), is of paramount interest for the translation process, because it helps trace the interaction between (translation) text analysis and social analysis. This means that, for instance, the criteria for certain translation decisions can be correlated with the habitus of the translator/s involved in specific historical moments, or may explain why certain translation strategies were adopted and others not in a particular relationship of time and space, and may perhaps reveal the translation product as the result of an intensive process of "negotiation." It may thus be discerned which prerequisites enable translatorial "negotiation," and which do not. But this also shows that the translatorial habitus not only results from social practice, but can also create values and produce knowledge related to action. So we see its constructing aspect and translation's potential for the manipulative.

Bourdieu's cultural sociology has been criticized from various perspectives. Bernard Lahire is doubtless the most severe critic of Bourdieu's work in general and his habitus concept in particular, both in terms of theoretical assessment and empirical proof. Lahire invited a number of scholars from various disciplines to critically re-assess Bourdieu's work through a constructive dialogue with the sociologist. In his book La culture des individus (Lahire 2004), the author scrutinizes several of Bourdieu's concepts, including the habitus, on the basis of more than 100 interviews in the form of portraits. According to this study, the individual is determined by multiple social experiences that exert influence throughout one's lifetime. Lahire

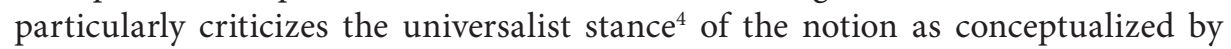
Bourdieu and argues that what seems more important is the analysis of the conditions which enable the formation of both a self-contained habitus and a strongly fragmented, contradictory habitus (Lahire 1998: 37). He claims that, instead, individuals draw on a vast array of dispositions which allow for a more differentiated view of their socialization. Consequently, when Lahire argues in favour of a sociology "at the level of the individual" (Lahire 2003) he stresses the view of individuals as products of pluriform social processes occurring in very different domains, and seeks to foreground the plurality of the individual's dispositions - for example, dispositions 
differ from one another in stability and strengths (Lahire 2003: 339) - and the multiplicity of different situations in which the agents interact.

To examine the translation process, Lahire's focus on the diverse modalities which prompt the habitus can better help to explain the conditions underlying translation strategies, and reconstructs both conscious and unconscious motives that trigger specific translation situations. However, Lahire's assertion that "dispositions become active under specific conditions only" (Lahire 2003: 342, original emphasis), points to the wide range of discursive practices operating in translation, in terms of the specific translation methods chosen by "tradition," as well as the constraints which also temporarily impact the translator's decisions. Some other important aspects raised by Lahire are his claim that Bourdieu's concept excludes, or never mentions the time specific agents spend outside the field where they are primarily active in the course of their position-taking. Similarly, the agents' shift between various fields is neglected. ${ }^{5}$ These two aspects are clearly of particular interest in the translation context. However, although highly dynamic, it appears that Lahire's "sociology of dispositions" over-emphasizes individual subjectivity. Applied to translation studies contexts, despite its deepening insights into the reflection of the translation process and its social implications, this theory neglects the powerful circumstances in which agents interact among one another in the process of shaping the emerging translation product. ${ }^{6}$

\section{The habitus in Translation Studies}

In recent years, several efforts have been made to open up to sociological concepts in translation studies: the "sociological eye" (Simeoni 2005: 12) has undeniably been sharpened. In what follows, my focus will be on the input of the habitus concept in shaping the discussion on the translation process. A number of translation scholars have drawn on the concept of habitus, not least to shed light on the social implications of translation and on the social dimension of the constraints operative in the translation procedure. This ongoing discussion on the role of habitus in the translation context will be briefly discussed, and an attempt made to assess its function to better understand the constraints underlying the translation process that ultimately define a translation's outlook.

As already mentioned by Gideon Toury in 1995, translators undergo a socialization process during which feedback procedures, mainly motivated by norms, are assimilated. This helps the translators to gradually develop strategies for coping with the various problems they encounter during actual translation, and in some cases translators might even adopt automatized techniques to resolve specific problems. This internalisation process is reminiscent of the translator's habitus and is conceptualized by Toury as follows:

It may also be hypothesized that to the extent that a norm has indeed been internalized and made part of a modified competence, it will also be applied to the production of more spontaneous translated utterances, in situations where no sanctions are likely to be imposed. [The translator's] behavioural varieties [...] may therefore prove a useful tool for checking not only the prevailing norms as such, but also their assimilation by individuals and, in the long run, the universals of the process of assimilation itself. (Toury 1995: 250) 
One of the first scholars who highlighted the importance of Bourdieu and the various categories of his cultural sociology for the study of translation was Jean-Marc Gouanvic. He has pointed out that Pierre Bourdieu's theory of cultural action can be widely applied to translation studies as it is a "sociology of the text as a production in the process of being carried out, of the product itself and of its consumption in the social fields, the whole seen in a relational manner" (Gouanvic 2005: 148). In his various works, Gouanvic describes the agents and various factors responsible for the creation of translation as a cultural product in specific institutions (translators, publishers, distributors, consumers, critics, consecrating agents, etc.) and comes to the conclusion that the stakes of translation are strongly legitimized practices, endowed with power on the basis of which the terms of translation operating between the various social spaces are continually renegotiated, thus being the driving force of the social game (Gouanvic 2002: 167). Gouanvic suggests that the constitution of a specific field of translation studies with its own structures, rules, and stakes, is only feasible through the work of those agents who have a symbolic or material interest in positioning themselves in this field, investing their "libido sciendi," their habitus and their scientific illusio (Gouvanvic 1999: 146). He stresses that during the translation procedure, the act of translating is heavily influenced by the translator's habitus and intimates that this habitus can be identified through the reconstruction of the translator's social trajectory. Gouanvic identifies the translator's habitus as a result of his or her practice from a specific habitus which is constructed while the cultures involved encounter one another during the transfer process. Consequently, translation strategies are generally not to be understood as deliberate choices, but rather in relation to the translator's habitus, which, together with that of other agents, structures the respective field and, in turn, is structured by the field itself (Gouanvic 2007: 86; 2005: 157-158).

As already mentioned, according to their habitus, the social agents (translators in this case) occupy a certain position in the social field in which they operate. I have shown elsewhere (Wolf 2007) that due to fundamental differences between the functional mechanisms operating in the production processes of "source" and "target texts" it seems problematic to reconstruct a "translation field" in Bourdieu's sense; this claim is also closely connected with the translatorial habitus. Daniel Simeoni argues that over the centuries the translatorial habitus has contributed to the internalization of a submissive behaviour, thus generating low social prestige for translators. In order to tackle the concept's complexity in the translation context, Simeoni makes a distinction between a "social" ("generalized") habitus and a "professional" ("specialized") one: "[...] becoming a translator is a matter of refining a social habitus into a special habitus” (Simeoni 1998: 19). As Rakefet Sela-Sheffy has rightly pointed out, however, this classification delimits the concept in suggesting that the habitus denotes the specific skills and preferences employed in translating (SelaSheffy 2005: 14). This explanation further suggests a linear development of translators' habitus during their professional training and their biographical trajectory.

Some of these remarks on the translatorial habitus imply clusters of questions which have been discussed in recent works on the issue: what is the relationship between translation norms and the translators' habitus? ${ }^{7}$ How does the habitus help create certain sections of literary fields through translation? And what is the potential for change inherent in the concept in the translatorial context? In the attempt to 
reframe Toury's concept of norms "on the assumption of a translating habitus understood as: (culturally) pre-structured and structuring agents meditating cultural artefacts in the course of transfer" (Simeoni 1998: 1), Daniel Simeoni tries to integrate the category of the translatorial habitus into systemic translation models. He argues that as a result of the continuous historically conditioned acceptance of norms on behalf of translators, the translators' willingness to accept these norms had a decisive impact on the secondary nature of their activity as such (Simeoni 1998: 6); consequently, this habitus leads to a marginal position in his (translatorial) field of practice. Moira Inghilleri also discusses the translator's/interpreter's assumed submissiveness, but claims to see an alternative to viewing - in this case - interpreters as "forever trapped inside their socially constituted selves" (Inghilleri 2003: 261). She elaborates a methodological framework for the analysis of community interpreting as normdriven activity and focuses on the constructivist nature of norms. This helps her to foreground the dynamics underlying the interplay of the distinctive and conflictual habitus of the agents involved in the process of community interpreting, which eventually make up the logics of the interpreting situation (Inghilleri 2003: 261). In a different context but with equally striking arguments, Rakefet Sela-Sheffy takes up Simeoni's efforts to relate habitus and norms. Similar to Inghilleri, she inserts the notions of conformity (as being akin to "obedience to norms") and divergence. These principles are viewed as strategies taken by actors in a certain field and under certain circumstances and are thus revealed as constructed entities (Sela-Sheffy 2005: 5).

The potential for change and transformation inherent in the discussions on the translator's submissive behaviour and its relationship to norms is another important aspect, which highlights the contribution of the notion of habitus in the understanding of the translation process in its social implications. Inghilleri argues that the major insights to be gained from Bourdieu's theory of symbolic forms for the study of translation can be found in his theorization of "the social," and suggests that the acts of translating and interpreting should be understood through the social practices in the fields where they are produced. One of the driving forces in formulating these practices is the agents' habitus, which, together with the competing forms of capital, creates the dynamics in the field and the ability to transform the forms of practice in which they engage (Inghilleri 2005: 143). This change is mainly engendered through "the embodiment of distinctive, contradictory and conflicting habitus amongst the participants [in the US American court interpreting field]," which results in the participants' different readings of the interpreting situation and the resulting challenge to the existing social relations (Inghilleri 2003: 261-262).

A sociologically informed translation (and interpreting) research which emphasizes the crucial role of habitus gives space to fine-grain analyses of the translation practice and discloses the habitus's interrelational character: through the process of incorporation it can be conceived of as structured principle, while the process of generation entails its structuring principle, as has been shown. The notion's historical character is opposed to the rather a-historically operating rules of "social acting" and instead implies constant alteration motivated by its creative capacity leading to new forms of behaviour. In such a view, the translatorial habitus not only results from the translation practice and retroacts upon it, but can also produce values and knowledge developed from translation practice, thus revealing its constructive nature and the potential for a manipulative component of the translation process. 


\section{The emerging translatorial habitus}

The following case study on the translator's habitus in the late Habsburg monarchy takes up, among others, the notorious "submissiveness" of translators, postulated by Simeoni. ${ }^{8}$ My claim is that as early as towards the end of the nineteenth century, the translators' activity was already characterized by certain emancipating processes, which became evident not only in a more self-conscious behaviour of translators as manifested in the paratexts of their translations, but also in re-enforced legitimation procedures in the field, like the creation and growing fostering of social networks and the struggle for recognition in the field.

In the late Habsburg Monarchy, about 50 million people were speaking 11 different languages. Their variants, of course, are not included. In fact, statistics on the Habsburg Monarchy's nationalities show its "Babelian" cultural and linguistic diversity: the German speaking and the Hungarian nationalities are the largest groups, followed by Czechs, Polish, Ukrainians, Romanians, Croatians, Serbs, Slovaks, and Slovenes, and finally the Italians, and Ladins. The census of 1910 gives the figure of 51.356.465 inhabitants. ${ }^{9}$

Consequently, the central government in Vienna and the local governments in the crown lands had to deal with the problems arising from this multilingual situation and were expected to guarantee the utmost communication between the various nationalities. In such a context, the phenomenon of translation, beyond its genuine pragmatic function of enabling or facilitating communication and cultural transfer, assumed a major role in shaping the various cultures involved in the continuous interaction between those cultures, implying both humans and symbols.

As will be shown, an investigation into the private translation sector in the last decades of the Habsburg Empire seems particularly revealing for the purpose of discussing an "emerging translatorial habitus." Private translation bureaus had been increasingly present in the last 30 years of the nineteenth century. Both professionally administered translation bureaus and the employment offers of private translators found their way into the address books of some of the major cities of the Monarchy, such as Vienna, Prague, Graz, and Ljubljana. An analysis of this booming business sector highlights its contribution to cope with the question of communication in the plurilingual space of the Habsburg Empire and in the realm of the multiple relationships with foreign countries. My analysis particularly focuses on the Viennese

\section{FIGURE 1}

Number of advertisements between 1876 and 1918 in Vienna (total of 718 entries)

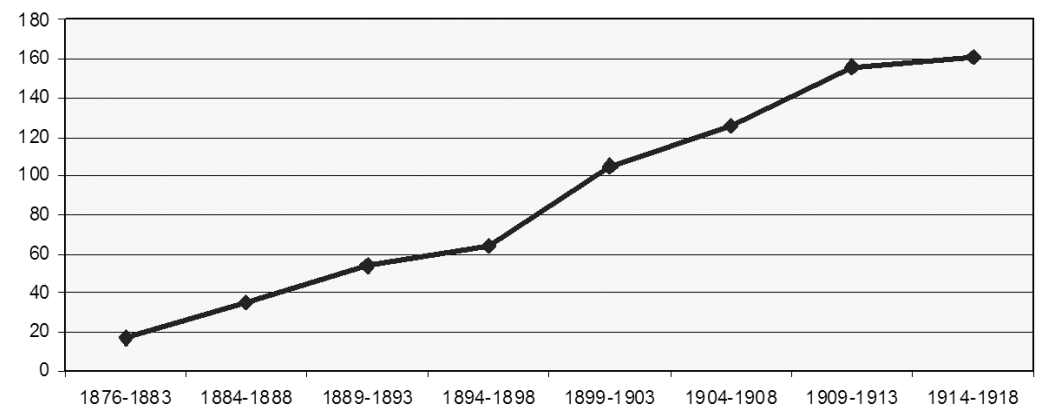


address book Adolph Lehmanns Allgemeiner Wohnungs-Anzeiger für die k.k. ReichsHaupt- und Residenzstadt Wien ${ }^{10}$, which includes the advertisements of translation bureaus for the first time in 1876 .

The growing number of advertisements reflects the increasing demand for commercial translations. ${ }^{11}$ While in 1876 the Anzeiger includes only one advertisement, this figure peaks at 37 in 1913. Similarly, the size of the entries reflects the emergent importance of the sector: while in the early decades the advertisements consisted of 2-3 lines, towards the end of the century they were often up to 12-25 lines. In the years just before World War I, some entries were as long as 60 lines and complete with their own layout. The total number of 718 advertisements in the years between 1876 and 1918 comprised bureaus (243) as well as individuals (475). In terms of gender, the field is heavily dominated by men: $84 \%$ of them refer to male names, $4 \%$ to female names (12\% of the names cannot be attributed due to abbreviations).

The ads generally gave the translator's/bureau's name and address (in later years also the telephone number), the source and target languages and the specialist areas for translation offered. In the period under investigation, translations into (and from) 23 languages were offered (Table 1)

TABLE 1

Languages offered for translation in advertisements ${ }^{12}$

\begin{tabular}{|c|c|c|}
\hline Arabic & English & Russian \\
\hline Armenian & French & Serbo-Croatian \\
\hline Bohemian & Hungarian & Slovakian \\
\hline Bosnian & Italian & Slovenian \\
\hline Bulgarian & Norwegian & Spanish \\
\hline Croatian & Polish & Swedish \\
\hline Danish & Portuguese & Turkish \\
\hline Dutch & Rumanian & \\
\hline
\end{tabular}

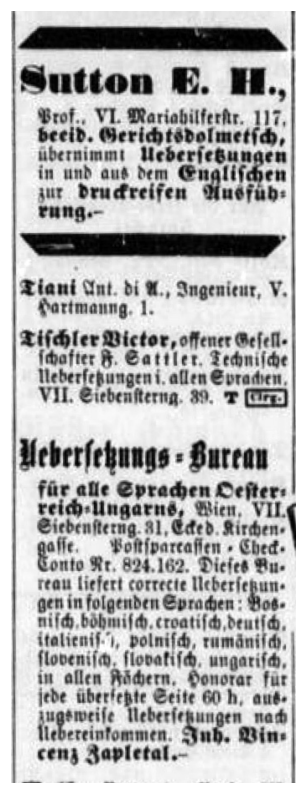

\section{FIGURE 2}

Advertisements of translation bureaus (from Lehmann 1903:744) ${ }^{13}$ 
The special fields offered for translation are an important indicator of the translation sector's increasing diversification. In the period under investigation, an average of $15 \%$ of the advertisements tells us that they cover "all special fields" ("alle Fachgebiete"). Over the years, however, we see an increasing number of additional areas of expertise. The largest number of services proposed to the clients is business correspondence (126 offers), followed by technical texts (120) and, surprisingly, novels (93). The services offered include all possible subject areas and text types, such as catalogues, leaflets, or journals; at a later stage they also offer the mechanical reproduction of these materials.

Equally diversified are the qualifications suggested by the bureaus: in the first few years, the information given in the advertisements is quite general and includes "business man," "journalist" or "clerk," which, at first sight, do not seem related to the translation activity. Later on, the translators emphasize their linguistic skills, indicating that they are "language teachers." After the turn of the century, translation related titles become more frequent: a considerable number call themselves "translator" (20 times, after 1897), followed by "court interpreter" (15, after 1905); other terms are "interpreter," "official translator," "graduate translator," and "linguist."14

Another line of qualification is evidenced on the translatorial experience and stresses both tradition (e. g. altestes und erstes allgemeines Übersetzungsbureau [oldest and first general translation bureau]) and internationality (Erstes Internationales Uebersetzungsbureau [First international translation bureau]); this qualification is further promoted through reference to "long experience abroad" and to pertinent professional experience acquired over many years, which is illustrated by figures such as "160,000 translations since 1880" (advertisement in 1900). The effort to be considered as a professional translator is reflected in about $12 \%$ of all advertisements in various types of statements. "The prompt attendance of the translation commission" is promoted as the prime necessity to accomplish the translation task and is expressed through formulations such as "prompt, at any time of the day," or "translation is being done immediately, while the errand-boy is waiting." The advertisements offer "impeccable" translations, "perfect in form and style" and "entirely correct"; accordingly, they advertise international commendation such as "pertinent certificates from Royal Ministries and Authorities from foreign countries." Of all advertisements $5 \%$ mention that the translation is produced in an "academically correct way," $2 \%$ praise their collaboration with academically trained professionals such as lawyers, doctors, etc., and some of them stress that they "not only uncritically translate from the dictionary." Equally, the description "Vienna's only institute under academic management" points to the effort to strive for a particularly high legitimation in the field.

The business aspects of the advertisements under investigation are quite surprising: only $9 \%$ include information concerning price. Only as late as the turn of the century do we start to see a more explicit rivalry between translation bureaus, with slogans such as "extremely low prices, cheaper than everywhere," or "very cheap, depending on language and text." The last slogan in particular indicates that the translation bureaus clearly distinguished between the languages and the material they translated. Their selection procedures clearly ascribed a certain prestige to the various cultures involved, thereby more or less consciously touting their position in the field. 


\section{4. (Re-)constructing the translator's habitus}

The brief presentation of the emerging profession of commercial translators shows that the dynamics in this new field were determined by a range of forces acting on different levels of practice. All of them attest to the gradual institutionalization happening within the field and the concomitant struggle towards autonomization. ${ }^{15}$ In what follows I will focus on three aspects to substantiate my claim that towards the end of the nineteenth century, the commercial translators' activity was already characterized by explicit emancipating processes mostly driven by the struggle for recognition in the field: the initially weak structure of the field, the habitus as a product of the relation between its collective and individual history, and the conditions triggering the dynamism of the translator's habitus.

\subsection{The structure of the translation field}

As I have discussed elsewhere (Wolf 2007), the translation field, like any other social field, evolves gradually through the efforts and stakes of its agents and participating institutions. But in the specific translation context, these efforts aren't seeking sustained relationships and the relatively weak structures stem from the ephemeral character of their bonds. Nonetheless, this field does not necessarily evolve ahistorically (see below). Indeed, during its structuration, the agents retrieve elements already existing in the field. For example, the translators emphasize quality criteria, and the agents' interests, which seem to appear only in specific situations or for particular cases of mediation, continually grow and can gain a collective momentum.

In addition, for many reasons translators are relegated to relatively low prestige. This will not be discussed in detail here, but two reasons might explain the rather weak structure of the translation field in the period under investigation. Firstly, the case study shows that many translators quite frequently practised their activity as a second profession (see below). Secondly, their professional job description was not protected by law (nor is it today), which meant that anyone involved in the activity of translating could call themselves a translator (or any other related job title) regardless of their qualifications in terms of translation competency. The shift from more general job titles such as clerk, journalist or businessman to profession-specific titles (language teacher, linguist, translator, (court) interpreter, or graduate translator) ${ }^{16}$ testify to the agents' increasingly inventive efforts to position themselves in the field. Among these designations, only court interpreter was a traditional and commonlyused professional title, but it was adopted in very specific workplace domains such as diplomatic interpreting and translation. Moreover, a court interpreter was not usually a freelance operation in the context discussed in this paper. ${ }^{17}$ It should also be stressed that in the Habsburg context the German word Translator - and not Übersetzer - had been used for centuries to refer to official translators. To give an example, after 1849, Translatoren were employed as civil servants in the Redaktionsbureau des Reichsgesetzblattes [Bureau of Redaction of the Imperial Law Gazette] where they translated all laws approved by the Reichstag into all the Empire's languages. ${ }^{18}$ One might conclude from this shift in the usage of titles that the steadily evolving translatorial habitus and the subsequent strengthening of the professional field had induced its central agents to strive for a more self-explanatory and selfreliant designation of their professional title. 


\subsection{The habitus resulting from collective and individual history}

Both the collective and the individual history are chief factors in the habitus's shaping process. The collective history can be seen as a set of various strands pertinent to the emerging profession of the commercial translator. Firstly, the translators' and translation bureaus' concerted efforts to gain positions in the field are evidence that they are not acting as novices. On the contrary, they utilize their mostly collective expertise as language teachers, literary translators, or court interpreters, moulded in the course of their ongoing experience in other fields. Secondly, the translators' struggle for professionalization, which can be detected in the various advertisements over the years, testifies to the translators' awareness that in a multilingual society like the Habsburg Monarchy translating was paramount to its functioning and to its business relations with other nations. Rakefet Sela-Sheffy mentions (in the context of her study on top literary and technical translators and their respective self-presentational discourses and status strategies) that professionalization processes tend to include "establishing professional organizations, diploma programs and academic training, as well as courses and workshops, developing working tools, and even proposing accreditation exams and a unified ethical code" (Sela-Sheffy 2010: 134). ${ }^{19}$ While most of these attempts were not (yet) applicable for the field of commercial translation in the Habsburg Monarchy during the period under investigation, the question of an ethical code was gaining momentum. Although not addressed directly, the striving for ethical standards is reflected in statements such as "correctness warranted," "it is guaranteed that translations are free from error," "translation are done with utmost scrupulosity" or "translators are fully competent." Such announcements (in about 9\% of all advertisements) signal the translators' integrity. Many proceeded conscientiously and cautiously, which seems to imply that their work as a translator in other fields (i.e., before entering the commercial translation field) had already undergone a serious inculcation process that strongly influenced their translatorial habitus. The collective nature of this habitus is discernable in the formulations of these ethically endowed statements: they all seem to draw on a set of ethical codes involving very similar wordings to announce their competence and accuracy.

The individual history affecting the formation of the translator's habitus is certainly closely linked to these processes. The forces at work are naturally more personal, such as the commendations listed by some translators attesting to their experience in very specific workplace domains ("translator at the Vienna City Council," "long-term assistant interpreter"). In doing so, the translators announce their own history experienced in other fields. Further evidence of this aspect is the pertinent professional experience acquired over many years mentioned in the case study and illustrated by figures such as "160,000 translations since 1880" (advertisement in 1900). The dynamics resulting from this "transition" further enhance the field and the evolving translatorial habitus.

\subsection{The dynamism of the translator's habitus}

The translatorial habitus thus plays a central role within the emerging field of the translation profession. It is evolving vigorously and a unifying action is happening which serves to re-construct "the" translatorial habitus in the specific field, but more 
important are the conditions of its generative nature and the dynamics underlying this process. Two points seem of paramount importance in this respect. On the one hand, the field in-the-making is not yet governed by an established set of rules, norms and conventions which can be met in other professional fields, one such example being the question of titles already discussed. On the other hand, the field's major agents generally come from other, mostly neighbouring fields (language teaching, journalism, etc.), and eventually run up against economic, ethical, and other constraints in the field. More specifically, we can distinguish between external and internal forces operating in the professional field that enable stronger habitus investment. First, the interaction of external forces with the field's agents shows up in the flourishing activities following the Trade Regulation Act of 1959 (Matis 1973). This Act was an important step towards trade liberalisation and facilitated the founding of private companies. Although the Monarchy continued to control the general direction and especially the limits of such liberalised activities, the private, commercially oriented initiatives born out of these new regulations were given relatively ample scope. The growing number of translation bureaus established in the last thirty years of the nineteenth century attests to these developments and likely resulted from the increasing demand for professional translation services in the wake of trade liberalization measures.

Many translators operating in the newly established field brought their professional experience - often combined with symbolic capital - acquired in other fields. These included teachers of the renowned "Orientalische Akademie" [Oriental Academy], an elite school originally commissioned by the Empress Maria Theresa in 1754 to train young diplomats to represent the Habsburg Monarchy abroad, especially in the Ottoman Empire. One such translator was Florance H. Hedley who in 1885 first offered his services in the Lehmann's Anzeiger, indicating only the languages he was working in and his postal address. One year later, he explicitly offered "political, technical, commercial and literary" translations and, as a "teacher of the English language," guaranteed that the translations would be "accurate and stylistically correct." Fourteen years later, in 1899 , he proudly publicized that he was now also teaching at the "Oriental Academy," thus visibly investing his cultural and symbolic capital in the field and simultaneously honing his translatorial habitus. Others earned their stripes as newspaper columnists or commentators on cultural affairs in various magazines and newspapers, such as Alois Sebera (1827-1909) who worked for the Botschafter and for the Deutsches Volksblatt in Vienna. Since the 1890s he was also the owner of a so-called "Literary Bureau" where he produced prologues, epilogues, "lectures in rhyme and prose" and occasional poetry (Brümmer 1913: 388). Although, in his case, this might explain the explicit inclusion of literary translation in his service offers, the combination of literary and commercial translation services was quite widespread. The advertisements frequently offered translation of fictional texts, presumably a badge of prestige in the eyes of potential clients. Of course, bringing the translator's expertise and alleged literary prestige into the professional field of predominantly commercial translation gave a considerable boost and affirmation to the collective translatorial habitus.

In addition to these external forces operating in the professional field which helped enhance the translators' habitus, the internal forces among agents in the field play a considerable role. The case study shows that these forces were particularly 
driven by the competition between the various translators offering services: the number of advertisements increased and became more descriptive over the years. They became more concerned with economic criteria, the number of languages offered increased steadily, and, more generally, we observe a stronger investment in the field on behalf of various capitals, including different forms of cultural capital. The "incorporated cultural capital," according to Bourdieu, can only be acquired personally and is the preliminary result of a long-term investment. It is generally "invested" in the form of products or services and is thus one of the main forms of capital in the professional field. In the period under investigation, the "incorporated cultural capital" is notably mentioned among the translators' qualifications. The languages offered in the advertisements are central to the translators' activity, and depending on the prestige of the language in question in the Monarchy's linguistic market, they decisively shape the translator's "position-taking" (Bourdieu 2008: 124) in the professional field. The recurring reference by translation bureaus to their "internationality" or the translators' international relations typify the reference to "incorporated cultural capital" while also overlapping with the social capital, thereby drawing on the social networks of all agents involved in the field. The importance of this capital is signalled by the high percentage (12\%) of the translators whose ads mention the internationality of their professional experience. Similarly, the special fields offered for translation are a vital indicator of the translation sector's increasing diversification and hence its professionalization. As mentioned above, between 1876 and $1918,15 \%$ of the advertisements indicate that they cover "all special fields." In this context, the statement by one of the translators that he collaborated in editing Sachs-Villatte's French dictionary (Bertrand Walko, 1902) also gives evidence of the "incorporated cultural capital." This means that the more differentiated the offer, the more skills and forms of knowledge the translators invest in their field, thereby selfpromoting in a privileged position. Equally, the time factor, mostly used to vaunt one's professionalism, plays an important role in shaping the translatorial habitus, as offers of "promptness" of service testify.

The "institutionalised cultural capital" is, according to Bourdieu (1986: 248; translated by Nice), of "conventional, constant, legally guaranteed value" and is generally the kind of capital that is certified in institutionally recognized educational degrees and academic titles. The translators' ads mention degrees or titles only to a limited extent: not more than $6 \%$ of all translators mention a $\mathrm{PhD}$, suggesting they may have a doctoral thesis in law, philology, or philosophy. One translator called himself "translator with diploma," without indicating the nature of the diploma.

As a metaphor for social power, the "social capital" designates the resources related to the affiliation with a certain group. The amount of "social capital" depends on the extent of the net of relations that can be mobilized by an agent (Bourdieu 1997: 63). In the advertisements under investigation the major factor of "social capital" is the commendations listed by the translators: $15 \%$ of all ads contain such commendations, pointing to the high value of this form of capital. Statements such as "membership in the General Writers' Association" or "special correspondent of the Prensa Española" highlight the translators' reliability and, subsequently, their reputation in the form of "symbolic capital."

All these capitals were invested by the translators in the professional field and continually shaped and refined their habitus as translators, also by adding some 
distinctive features to their overall professional habitus generally brought to the field of commercial translation from their practice and experience in other fields. By drawing on external and internal forces nourished by various forms of capital, the struggle in the professional field gradually created a habitus which, amid growing competition, became increasingly strong. Bourdieu reminds us that the "struggle itself creates the history of the field; through the struggle the field is given a temporal dimension" (Bourdieu 1980: 289, original emphasis) - thus, the habitus, too, can never be seen as a stable unit, but is continually subject to change and dynamic transformation.

\section{Concluding remarks}

The case study has shown that a supposedly subservient and normative character of the translators's habitus cannot be generally assumed. This raises several questions: can such a habitus be universally claimed? Or is it more realistic to say that - not least on the basis of my case study which focused on the shaping of a "field of commercial translation" within a special cultural and historical framework - it has not yet been developed or established sufficiently? If this is the case, wouldn't it imply a quite linear development of the habitus over time?

For the case in point, it seems obvious that the translatorial habitus prevailing in the period under investigation is positioned at the intersection of the agents' social practice and the social structure of the field. It was determined by the struggle to become established in the field of commercial translation which in turn spurred greater efforts by these agents to exploit all available competencies for this purpose. In more general terms, though to varying degrees, it can be stated that, in history and presence, the field responds to the rules of the market and, according to the forces conditioning these rules, the nature and especially the concentration of the capitals invested in the field vary and ultimately shape the entire structure of the field. As the case study has shown, however, a professional habitus, being shaped through experience and legitimation and struggling for recognition, further enforces the dynamics of the field and continually challenges the power relations inherent in this social space. A conceptualization of the habitus aimed at better understanding the functional mechanisms of translation and interpreting processes thus demands consideration, both within social situativeness and in connection with specific transculture aspects that acknowledge the habitus's location in space and time. What seems at stake is the need for insight "into [the involved actors'] various and variable internalization of broader social, cultural, political and linguistic structures, of both the institutional and discursive kind," as Reine Meylaerts has rightly pointed out (Meylaerts 2008: 95, original emphasis). Possibly, in completing Bourdieu's concept of habitus and in view of the specific character of the translatorial agency, Lahire's notion described earlier could help elucidate the factors that condition the translator's socialization in the professional field and which foreground the great variety of translator's dispositions, not least in order to allow for crucial insights into the decisions taken during the translation procedure and simultaneously deepen the understanding of the social relevance and responsibility of the agents participating in the translation process. 


\section{NOTES}

1. It seems indicative that Panofsky's German text in which he discussed scholastic thinking had been translated to French by Bourdieu - one of the few translations produced by the sociologist (see Panofsky 1967/2000).

2. Another scholastic scholar who based his concept of habitus on Aristotle is Jean Duns Scotus (about 1266-1308), who was one of the most important and influential philosopher-theologians of the High Middle Ages (for his use of the term, see Williams (2009). For further reading of the term's history, see especially Nickl 2001.

3. Blunden, Andy, ed. (2005): Habitus. Encyclopedia of Marxism. With the collaboration of Brian Baggins (Co-editor 1999-2007), Sally Ryan, and David Walters, Sertan Batur, Arthur Nehru, Mathais Bismo. Marxism Internet Archives. Visited on 15 December 2013, <http://www.marxists. org/glossary/terms/h/a.htm\#habitus>.

4. For the historical aspect of this critique, see Calhoun 1993.

5. For this last point, also in the translation context, see particularly Wolf 2007.

6. Another point often criticized is Bourdieu's focus on national societies only (see e.g., Meylaerts 2006). This might be true for his work on the literary field, political field and others up to the 1980s more or less; at the latest when Bourdieu enters the research area of the publishing sector (see especially Bourdieu 2002 and 2008), this is no longer true. See also Heilbron and Sapiro 2002).

7. For habitus in the context of DTS, see Meylaerts 2008.

8. For more details, see Wolf 2012.

9. Österreichische Statistik (1912): Neue Folge. Die Ergebnisse der Volkszählung vom 31. Dezember 1910 in den im Reichsrate vertretenen Königreichen und Ländern. Vol. 1. Issue 1. Vienna: Gerold.

10. Lehmann, Adolph (1876-1918): Lehmanns Allgemeiner Wohnungs-Anzeiger nebst Handels- und Gewerbe-Adreßbuch für die k.k. ReichsHaupt- und Residenzstadt Wien und Umgebung. Vienna: Hölder. Visited on 15 December 2013, <http://www.digital.wienbibliothek.at/nav/classification/ 2609>.

11. Interpretations were offered only in $4 \%$ of all ads and will not be discussed in the context of this paper.

12. Additionally, several language groups were offered, such as "Slavic," "Romance," "Germanic," or "Eastern Asiatic." This table, however, is not representative, as nearly half of the entries did not include languages.

13. Lehmann, Adolph (1903): Lehmanns Allgemeiner Wohnungs-Anzeiger nebst Handels- und Gewerbe-Adreßbuch für die k.k. ReichsHaupt- und Residenzstadt Wien und Umgebung. Vienna: Hölder, 744. Visited on 15 December 2013, <http://www.digital.wienbibliothek.at/wbrobv/periodical/pageview/93057>

14. The German word for translator is Übersetzer. In the Habsburg context, however, the German word Translator - and not Übersetzer - had been used for centuries to refer to official translators.

15. See Wolf (2012: 209) for the relationship between institutionalization and the strive for autonomy in the field.

16. Unfortunately, it is not known which training or education underlay these self-conferred professional designations.

17. See Reiter 2010 for the profession of the court interpreter (Hofdolmetscher) in the Habsburg Monarchy.

18. Other translators were employed in the "Ciphering and Translatorial Work Section" (Sektion für Chiffrewesen und translatorische Arbeiten). It was part of the Foreign Ministry and its main task was to open suspect letters, to decipher them if they were coded and to translate them, if necessary (Wolf 2012: 165-172).

19. Esther Monzó's statements on the professionalization process (Monzó 2009: 137) particularly focus on the "upsurge of institutionalized discourses, perceptions, constructions and actions" which, however, cannot yet be detected in the case under investigation. This seems to prove that the field of commercial translation was indeed still quite weakly structured. 


\section{REFERENCES}

Bourdieu, Pierre (1977): Outline of a Theory of Practice. (Translated by Richard NicE) Cambridge: Cambridge University Press.

Bourdieu, Pierre (1980): The Production of Belief: Contribution to an Economy of Symbolic Goods. Media, Culture and Society 2:261-293.

Bourdieu, Pierre (1986): The Forms of Capital. In: John G. Richardson, ed. Handbook of Theory and Research for the Sociology of Education (Translated by Richard NICE) New York: Greenwood Press, 241-258.

Bourdieu, Pierre (1989): Social and Symbolic Power. Sociological Theory. 7:14-25.

Bourdieu, Pierre (1990a): In Other Words: Essays Towards a Reflexive Sociology. (Translated by Matthew Adamson). Stanford: Stanford University Press.

Bourdieu, Pierre (1990b): The Logic of Practice. (Translated by Richard NicE) Cambridge: Polity Press.

Bourdieu, Pierre (1991): Questions of Method. In: Elrud IвSCH, Dick Schram and Gerard STEEN, eds. Empirical Studies of Literature. (Second Conference of the International Association of the Empirical Study of Literature, Vrije University, Amsterdam, December 1989). Amsterdam/Atlanta: Rodopi, 19-36.

Bourdieu, Pierre (1992): Rede und Antwort. (Translated by Bernd ScHwiBs) Frankfurt am Main: Suhrkamp.

Bourdieu, Pierre (1993): The Field of Cultural Production: Essays on Art and Literature. In: Randal Johnson, ed. (Several translators; Chapter 1 translated by Richard NiCE) Cambridge: Polity Press.

Bourdieu, Pierre (1997): Die verborgenen Mechanismen der Macht - Schriften zu Politik \& Kultur 1. Hamburg: VSA-Verlag.

Bourdieu, Pierre (2002): Les conditions sociales de la circulation internationale des idées. Actes de la recherche en sciences sociales. 145:3-8.

Bourdieu, Pierre (2008): A Conservative Revolution in Publishing. (Translated by Ryan Fraser) Translation Studies. 1(2):123-153.

Brümmer, Franz, ed. (1913): Lexikon der deutschen Dichter und Prosaisten vom Beginn des 19. Jahrhunderts bis zur Gegenwart. $6^{\text {th }}$ ed. Vol. 6. Leipzig: Reclam.

Calmoun, Craig (1993): Habitus, Field, and Capital: The Question of Historical Specificity. In: Craig Calhoun, Moishe Postone and Edward LiPuma, eds. Bourdieu: Critical Perspectives. Chicago: Chicago University Press, 61-88.

Elias, Norbert (1987): Die Gesellschaft der Individuen. Frankfurt am Main: Suhrkamp.

GouAnvic, Jean-Marc (1999): Sociologie de la traduction. La science-fiction américaine dans l'espace culturel français des années 1950. Arras Cedex: Artois Presses Université.

GouAnvic, Jean-Marc (2002): The Stakes of Translation in Literary Fields. Across Languages and Cultures. 3(2):159-168.

GouAnvic, Jean-Marc (2005): A Bourdieusian Theory of Translation, or the Coincidence of Practical Instances: Field, "Habitus," Capital and "Illusio." The Translator. 11(2):147-166.

Gouanvic, Jean-Marc (2007): Objectivation, réflexivité et traduction. Pour une re-lecture bourdiesienne de la traduction. In: Michaela Wolf and Alexandra Fukari, eds. Constructing a Sociology of Translation. Amsterdam/Philadelphia: John Benjamins, 79-92.

Heilbron, Johan and SAPIro, Gisèle (2002): La traduction littéraire, un objet sociologique. Actes de la recherche en sciences sociales. 144:3-6.

Inghilleri, Moira (2003): Habitus, Field and Discourse. Interpreting as a Socially Situated Activity. Target. 15(2):243-268.

INGHILLERI, Moira (2005): The Sociology of Bourdieu and the Construction of the "Object" in Translation and Interpreting Studies. The Translator. 11(2):125-145.

Jenkins, Richard (1992): Pierre Bourdieu. London/New York: Routledge.

Johnson, Randal, ed. (1993): Pierre Bourdieu on Art, Literature and Culture. In: Pierre BourDieu. The Field of Cultural Production. In: Randal Johnson, ed. Cambridge: Polity Press, 1-25. 
Krais, Beate and Gebauer, Günter (2002): Habitus. Bielefeld: Transcript.

LAHIRE, Bernard (1998): L'homme pluriel. Les resorts de l'action. Paris: Hachette.

LAHIRE, Bernard (2003): From the Habitus to an Individual Heritage of Dispositions. Towards a Sociology at the Level of the Individual. Poetics 31:329-355.

Lahire, Bernard (2004): La culture des individus. Dissonances culturelles et distinction de soi. Paris: La Découverte.

Lehmann, Adolph (1876-1918): Lehmanns Allgemeiner Wohnungs-Anzeiger nebst Handels- und Gewerbe-Adreßbuch für die k.k. ReichsHaupt- und Residenzstadt Wien und Umgebung. Vienna: Hölder.

Malikail, Joseph (2003): Moral Character: Hexis, Habitus and "Habit." Minerva - An Internet Journal of Philosophy. 7:online. Visited on 15 December 2013, <http://www.ul.ie/ philos/ vol7/moral.html>.

Matis, Herbert (1973): Leitlinien der österreichischen Wirtschaftspolitik. In: Adam WaNDRUSZKa and Peter Urbanitsch, eds. Die Habsburgermonarchie 1848-1918. Vol. 1. Vienna: Verlag der Österreichischen Akademie der Wissenschaften, 29-67.

Meylaerts, Reine (2006): Conceptualizing the Translator as a Historical Subject in Multilingual Environments. In: Georges L. BAstin and Paul F. BAndia, eds. Charting the Future of Translation History. Ottawa: University of Ottawa Press, 59-79.

Meylaerts, Reine (2008): Translators and (their) Norms. Towards a Sociological Construction of the Individual. In: Anthony Pym, Miriam Shlesinger and Daniel Simeoni, eds. Beyond Descriptive Translation Studies. Investigations in Homage to Gideon Toury. Amsterdam/ Philadelphia: John Benjamins, 91-102.

Monzó, Esther (2009): Legal and Translational Occupations in Spain. Translation and Interpreting Studies. 4(2):135-154.

NickL, Peter (2001): Ordnung der Gefühle. Studien zum Begriff des Habitus. Hamburg: Meiner Verlag.

PANofsky, Erwin (1967): Architecture gothique et pensée scolastique. (Translated by Pierre Bourdieu). Paris: Minuit.

Reiter, Clara (2010): “... und anfangs zum k.k. Hofdollmetscher ebendaselbst befördert”: Aufden Spuren der Hofdolmetscher in der Habsburgermonarchie. Diploma thesis, unpublished. Graz: University of Graz.

SCAHILl, John H. (1993): Meaning-construction and Habitus. Philosophy of Education. 1993. Visited on 1 August 2011, <http://www.ed.uiuc.edu/eps/PES-Yearbook/93_docs/SCAHILL. HTM>.

Sela-Sheffy, Rakefet (2005): How to be a (Recognized) Translator. Rethinking Habitus, Norms, and the Field of Translation. Target. 17(1):1-26.

Sela-Sheffy, Rakefet (2010): "Stars" or "Professionals": The Imagined Vocation and Exclusive Knowledge of Translators in Israel. In: Oscar Diaz FoucEs and Esther Monzó, eds. MonTI 2: Applied Sociology in Translation Studies, 131-152.

Simeoni, Daniel (1998): The Pivotal Status of the Translator's Habitus. Target 10(1):1-39.

Simeoni, Daniel (2005): Translation and Society: The Emergence of a Conceptual Relationship. In: Paul St-Pierre and Prafulla C. Kar, eds. In Translation. Reflections, Refractions, Transformations. Delhi: Pencraft International, 3-14.

Toury, Gideon (1995): Descriptive Translation Studies and Beyond. Amsterdam/Philadelphia: John Benjamins.

Williams, Thomas (2009): John Duns Scotus. In: Stanford Encyclopedia of Philosophy. Visited on 30 March 2012, <http://plato.stanford.edu/entries/duns-scotus/>.

Wolf, Michaela (2007): The Location of the "Translation Field": Negotiating Borderlines Between Pierre Bourdieu and Homi Bhabha. In: Michaela Wolf and Alexandra Fukari, eds. Constructing a Sociology of Translation. Amsterdam/Philadelphia: Benjamins, 109-119.

Wolf, Michaela (2012): Die vielsprachige Seele Kakaniens. Übersetzen und Dolmetschen in der Habsburgermonarchie 1848 bis 1918. Wien/Köln/Weimar: Böhlau. 